\title{
Textile industry's environmental effects and approaching cleaner production and sustainability, an overview
}

\begin{abstract}
The public awareness and the growing perception of social cognizance about the environment have forced the textile industry to produce environmentally friendly products. For this reason, nowadays many companies and organizations focus on the environmentally friendly way of production. In order to create a sustainable textile, the main change factors have been linked to eco-materials so less and harmless waste, reusing/recycling, lesser usage of energy, water and chemicals and ethical issues in production processes. This article emphasizes the environmental effects of textiles in detail and contributes to cleaner production and sustainability in the textile industry by initiating a discussion on the opportunities for change in textile processes in accordance with the laws.
\end{abstract}

Keywords: cleaner production, environmentally friendly, greener production, sustainability, textile
Volume 2 Issue 4 - 2017

\author{
Tuba Toprak, Pervin Anis \\ Department of Textile Engineering, Engineering Faculty, Uludag \\ University, Turkey
}

\begin{abstract}
Correspondence: Tuba Toprak, Department of Textile Engineering, Engineering Faculty, Uludag University, Bursa, Turkey, Tel 902242942009 , Email tubatoprak@uludag.edu.tr
\end{abstract}

Received: July 06, 2017 | Published: August 10, 2017
Abbreviations: EIA, environmental impact assessment; EMS, environmental management system; LCA, life cycle assessment; IS, industrial symbiosis; GWP, global warming potential; UNEP, united nations environment programme; UNIDO, united nations industrial development organization; OECD, organization for economic co-operation and development; OEEC, organization for european economic cooperation; WBCSD, world business council for sustainable development; WICE, world industry Council for the Environment; BCSD, business council for sustainable development; NIH, national institute of health; BOD, biological oxygen demand; TSS, total suspended solids; COD, chemical oxygen demand; AOX, adsorbable organic halogens; APEOs, alkyl phenol ethoxylates; PFOS, perfluoro octane sulphonate; PFOA, perfluorooctanoic acid; PBDEs, polybrominated diphenyl ethers; PVA, polyvinyl alcohol; UF, ultrafiltration; RO, reverse osmosis; VFE, vacuum flash evaporation; LCI, life-cycle inventory; EU, european union

\section{Introduction, is development or environment more important?}

The extraordinary expansion of the global economy in recent years has also caused the explosion in consumption. While some of this growth in consumption is necessary for people to continue their lives, the rest is not. Like richness, consumption is also showing uneven distribution. Even though consumption of per person has risen in large areas of the world, these increases are not the same for everybody, and the differences between the increases are huge. $86 \%$ of personal consumption outlays are carried out by the richest unions of the world, while the poor are consuming $1.3 \%$. A person in North America is estimated to average about 20 times more than a person in China or India and about 65 times more than someone in Bangladesh. Today, the expenditures of 100 million people living in industrially developed regions correspond to the consumption of more than one billion people living in underdeveloped regions of the world, just to meet fundamental requirements. This case is problematic because it has two contradictory appearances and both of them put great pressure on the global environment. ${ }^{1,2}$

People who can not even use up sufficient to supply their fundamental requirements are compelled to make short-range verdicts that often have adverse long-dated effects on the environment to meet their needs. Examples of environmental problems caused by low consumption and poverty include cyanide fisheries which threatening the reef ecosystem of poor fishermen in Southeast Asia, farmers in Africa burning trees for rice bread, destroying forests and increasing poverty and deprivation by accelerating erosion and desertification. ${ }^{1}$

Advanced production technologies, which are used to meet increased consumption demands, have also made production activities important to the global environment. The developing technology brought about the problems like pollution of the environment, air, and water, thinning of the ozone layer, a decrease of green areas. In response, however, a public opinion has emerged, especially in developed countries, that is sensitive to these problems. New precautions have begun to be considered both to maintain industrialization and to protect the environment. It has been shown that cleaning up after the pollution is more costly than cleaning up before the pollution, and it is not possible to restore the degraded ecological balance after pollution. This led to the discussion of "how can we industrialize by protecting environmental values" instead of "development or environment is more important". ${ }^{3}$

Along with the technological developments in recent years, developments in the textile sector as well as in many sectors have played a major role in the increase of environmental problems. The main environmental impact in the textile industry is manifested by the discharge of high amounts of chemical loads into the receiving environment. Other important elements are high chemical and water use, energy consumption, air pollution, solid waste and odor formation. Environmental issues related to textile and garment sector; it starts with drugs that are used in the cultivation of natural fibers and 
the emissions in the production of synthetic fibers. From this moment on, a series of processes are being carried out in which thousands of different chemicals, tons of water and considerable amount of energy are used to treat the fibers to reach the final textile product. In this review study, the environmental problems that textile has emerged have been examined and it has been explained that solutions for the problems can be made within the scope of sustainability and cleaner production. The concept of cleaner production has also been discussed in detail and the relationship with sustainability has been put forward.

\section{Environmental actions and cleaner produc- tion}

Reactions to environmental problems began with local movements in the 1960s, leaving the place to environmental organizations and parties in the 1970s. The Quality Management System (ISO 9000), published by ISO in 1987, forced industrialists to contemplate the environment by minimizing the raw materials usage, reducing the use of energy in processes or searching for clean energy sources, using non-harmful packaging materials and destroying them easily. Therefore, cleaner production and sustainability have been offered as solutions to environmental problems. The concept of "cleaner production", which is often used in many countries, has evolved into the concept of "sustainable production" in the last 10 years in order to prevent possible future bigger catastrophes. Sustainable production has become widespread with the cleaner production concept used by many organizations. ${ }^{4}$

Cleaner production definition was made by UNEP in 1989 as "continuous application of an integrated, preventive environmental strategy towards processes, products, and services in order to increase overall efficiency and reduce damage and risks for humans and the environment". Later, this definition was widened via joining the sustainable development orientation. For example, in 2004, direct participation in the economic dimension of recognition by means of "using better management strategies, methods, and tools" was provided. ${ }^{5}$ Cleaner production has been applied as for production processes; protection of raw materials and energy, removal of poisonous substances and accordingly abatement of toxic emissions and waste of products, for products; preventing or reducing the adverse effects of a product throughout the life cycle, for services; including environmental anxiety to design and distribution services. In summary, cleaner production; continuous implementation of an environmental protection strategy integrated with processes, products, and services. ${ }^{6}$

The first approach, which is used extensively to protect environmental values, is to eliminate pollution after it has been formed. "Pollution control", also referred to as the "end of pipe" approach focuses on the ways in which production and design phases are invariably adopted, and that pollution is the inevitable consequence of this, and therefore the better definition and elimination of pollution. This brings significant additional investment costs to the organization and high investment requirements are met with frustration by individuals or institutions in some areas and countries. Continuous increase in the amount of wastes generated in the process and the cost of the purification treatments, the continuous improvement of the receiving environment discharge standards and the environmental consciousness of public has forced the product and service sectors to find cheaper solutions. As a result of this tendency, with simple measures, more effective use of raw materials that do not form beneficial products at the end of production and become waste, they have been seen that these losses are reduced, therefore, waste production can be reduced. This has been followed by approaches such as increasing the productivity, replacing the raw materials with those less harmful to the environment and reducing water and energy needs in the production and usage processes. These have contributed to the acceleration of work on waste reduction, recycling, reuse, environmentally sensitive product and service design, etc. and ensured that the "cleaner production" approach instead of the "end of pipe". 7 The percentages of using them in different OECD countries are given in Figure 1.

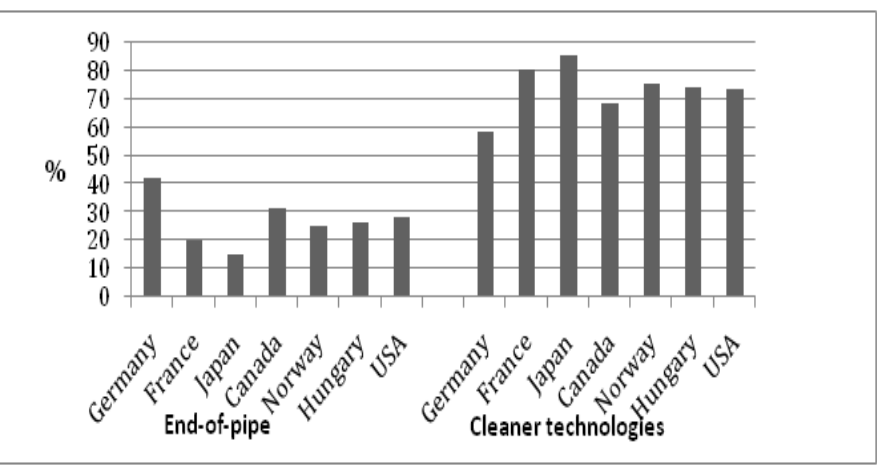

Figure I Selection of environmental technologies in the OECD countries. ${ }^{97}$

\section{Cleaner production applications}

Cleaner production applications can be classified into three main categories,

a. Reduction of waste and reduction of resource consumption,

b. Reuse and/or recycling,

c. Product modifications. ${ }^{8}$

\section{Practices for waste reduction at source}

i. Administrative preventions: It is one of the simplest methods of cleaner production and it is not costly because there is no investment and it can be put into practice immediately after determining the possibilities. Examples are the prevention of water, energy and other source losses such as keeping the water vents closed, optimizing chemical dosing, wasting equipment, etc. Moreover, focusing on the management and training of employees can also be done under this heading.

ii. Better process control: Within this heading; temperature, time, pressure, $\mathrm{pH}$, process speed etc. are to be checked to see if they are optimum in terms of welding consumables, production, and waste production, and to make appropriate changes if necessary. This part requires more complex monitoring and management than administrative measures.

iii. Material substitution: This means that the productivity of the production is increased by the use of a higher quality material without compromising quality and cost. In addition, material substitution also means replacing existing materials with some more environmentally friendly materials. For example, replacing a dyestuff containing a hazardous chemical with an environmentally friendly one means that the purification requirements and costs that would be caused by the hazardous chemical substance are either eliminating or falling down. 
iv. Equipment modification: Equipment modification is the development of present equipment to produce fewer waste and to ensure more efficient production processes. Examples include setting engine speeds, optimizing tank volumes, isolation of hot pipes, and so on

v. New process technology: Because this method involves the use of more modern and efficient technologies, it requires a higher initial investment cost than other methods. However, with the developments of quality and savings the investment can be repaid in a very short-dated and with this application the company can more easily switch to more up-to-date and modern production processes. Such applications also provide improvements in product and production quality. ${ }^{8-10}$

Reuse/Recycling: Reusing rinse water from one process to another cleaning process is an example of on-site recycling or reuse. It involves collecting waste and reusing it in the same or different parts of the production. Non-preventable wastes can be recycled or vend as an offshoot. This includes the creation of by-products, the sale of waste to consumers or other firms after collection of waste. For example; waste yeast, which is released in the brewery, can be reused as animal feed, fish production and food additive substance. ${ }^{9,10}$

Product modification: One of the basic headings of cleaner production to reduce the pollution caused by products is to change product characteristics. Changing the product requires that the product and its requirements be reviewed again. Reducing the weight and the thickness of the products, designing that allows the product to be more easily recycled, changing the packaging are examples of this approa$\mathrm{ch}$. The main point of view in the change of packaging is that the protection of the product is guaranteed by the minimum amount of packaging material. ${ }^{8}$

\section{Tools and methods for cleaner production}

The choice of which tools are used to determine the use of cleaner production opportunities according to their application areas depends on the problem in operation and the work to be done. Single or multiple tools can be used based on nature of the problem. ${ }^{11}$

Environmental impact assessment (EIA): This is a procedure, which provides that environmental effects are taken into account before making decisions. EIA includes identification of the positive and negative effects of the planned projects on the environment, determination of the measures to be taken to forestall and decrease these negative effects, and monitoring the implementation of the projects. $^{12}$

Environmental management system (EMS): It aims at the management of activities that are linked to each other, have an environmental impact or have potency. Phases of this system; environmental policy, planning, implementation and operation, control and correction process, management inspection. It provides a mechanism to firms for thinking about the environment, deciding what to do and planning how to do it, actually applying it, and correcting deviations in the plan. ${ }^{13}$

Life cycle assessment (LCA): It also named "life cycle analysis", "life cycle approach", "cradle to grave analysis" or "eco balance", includes an assessment of aspects of a product system that are generally relevant to the environment at entire phases of its life cycle. In other sense, it is the cluster of means and methods that have emerged to aid in environmental management for sustainable development. ${ }^{14}$ The LCA can be used to systematically analyze and to prevent/mitigate negative impacts on the environment caused by the goods and services from production to disposal, and to determine resources used throughout their life cycle and to improve opportunities. ${ }^{10}$

Environmental technology evaluation: Environmental impact assessments of various plants and projects involve the discharge of the use of various technologies and the determination of the risks of these technologies on human health and environmental values using qualitative and quantitative methods. In summary, it examines the effects of a specific technology on human health and natural systems and resources. ${ }^{11}$

Chemical evaluation: In this context, the toxic effects and quantities of the chemical substances used in the production phase are analyzed to evaluate jeopardy on the health of human and the environment. It also includes methodologies for hazard and exposure assessment. ${ }^{15}$

Waste inspection: Input/output inventories of processes, source, quality and quantity of wastes generated, efficiency and weak points of the current process, waste minimization targets for cleaner production are determined with waste control. Thus, losses are reduced/prevented to increase process efficiency. ${ }^{10}$

Environmental inspection: It is the most commonly used and most important application tool of cleaner production. Its scopes to specify the quantity and character of the waste from the production process/services and to make decisions about what needs to be done to reduce the pollution. Because it is a very effective tool, there are types developed for different purposes such as waste, energy and risk monitoring. ${ }^{11}$

Eco-label/environmental labeling: An eco-label indicates that a product or service is sensitive to the environment in a particular category. Ecolabelling is implemented worldwide and is a voluntary method for certificating environmental performance. ${ }^{16}$

Industrial symbiosis (IS): "The principle behind industrial symbiosis is quite simple; instead of being thrown away or destroyed, surplus resources generated by an industrial process are captured then redirected for use as a 'new' input into another process by one or more other companies, providing a mutual benefit or symbiosis". ${ }^{17}$ Working together via industrial symbiosis, companies look for gaining competitive advantage through the barter of energy, materials, water, by-products, waste or common usage of logistics, specialty etc. In this way, they can increase operating efficiencies, save money, reduce their environmental impact, share knowledge, encourage ecodiscovery and longtime culture alter. ${ }^{18}$

Water footprint: For a single process or product, it measures the volume of clean water consumed and/or contaminated by humanity. It may also indicate how much water is consumed from a particular river basin or aquifer from globally/country. ${ }^{19}$

Carbon footprint: The carbon footprint that comes to mind with the climate change problem is described as the sum amount of greenhouse gasses which spread by an institution, person, activity or product. According to the definition of Wiedmann et al. ${ }^{20}$ "The carbon footprint is a measure of the exclusive total amount of carbon dioxide emissions that is directly and indirectly caused by an activity or is accumulated over the life stages of a product". $\mathrm{CO}_{2}$ equivalents or Global Warming Potential (GWP) was described as how many other greenhouse gasses have the same heat holding capacity in the atmosphere compared to the same amount of $\mathrm{CO}_{2}$ for a given period of time. With this unit, the effect of all greenhouse gasses can be collected and expressed in a common unit. ${ }^{21}$

Risk assessment: The risks to be caused by a specific event on 
sanitary of human and the surrounding and the precautions to be taken about these risks are determined by this method. ${ }^{10}$ Policy instruments applied to encourage cleaner production may include legal legislation, voluntary standards, economic instruments (taxes and penalties, state aid, financial mechanisms, etc.), information and technical assistance.

\section{International organizations and Institutions for clea- ner production}

The United Nations Environment Programme (UNEP): It is an initiative that, one of the main global environmental authorities, as a defender of the environment, sets the environmental agenda globally and encourages consistent application of the environmental dimension of sustainable development. Set up in 1972, UNEP initiated work on the cleaner production in 1989 with the decision to "find environmentally sensitive technologies". In 1990, the International Cleaner Production Information Network was established through the Cleaner Production Program and the Cleaner Production Centers were established with UNIDO partnership to develop capacity development projects in the developing countries. UNEP also publishes several publications showing the advantages of cleaner production. ${ }^{22}$

The United Nations Industrial Development Organization (UNIDO): Constituted in 1966 to accelerate transition economies and sustainable industrial growing in ongoingness countries, UNIDO is a private representative of the United Nations. UNIDO supports industrial development, globalization and environmental sustainability for poverty reduction. ${ }^{23}$

The Organization For Economic Co-Operation And Development (OECD): It was established in the aftermath of the II. World War on the completion of the function of the Organization for European Economic Cooperation (OEEC), which operated between 1947-1960, in its place and on the basis of broader tasks. The organization has 35 countries with democratic structures and market economies to work together to solve economic, social and management problems of globalization and to take advantage of this process opportunities. ${ }^{24}$ The OECD has achieved many successes in cleaner production over 20 years. In 1990, it started the Technology and Environment Program which lasted 3 years. Within this program, awareness of clean technologies was established, governments roles and responsibilities were defined, new analytical tools for cleaner production were identified, deficiencies in technology transfer and innovation were determined, cleaner production expert network was established and conferences were organized. ${ }^{25}$

The World Business Council For Sustainable Development (WBCSD): It was formed by merging the Business Council for Sustainable Development (BCSD) and the World Industry Council for the Environment (WICE) on 1995. It is a global organization created by more than 200 leading companies working together to speed up the passing to a more sustainable world. It has been involved in several cleaner production projects with UNEP. ${ }^{26}$

\section{Sustainability}

Sustainable development is a problematic issue ${ }^{27}$ and Brundtland Commission made its most famous and valid definition in 1987. Sustainability was described as "meeting the needs of today's needs without compromising the ability of future generations to meet their own needs". ${ }^{28}$ In the economy of sustainable development; consumption of resources, the non-renewable energy sources or the destruction of valuable natural capital is not permitted. ${ }^{29}$ In this regard, sustainable development can be identified as a balance between man and environment, programming the life and development of todays and future generations in such a way as to enable them to meet and develop the needs of future generations. ${ }^{30}$ Sustainability, the goal of sustainable development, has many meanings today. According to Frankel, ${ }^{31}$ Elkington ${ }^{32}$ while sustainability is the balance between economy, environment, and social equality, sustainability according to Gilding ${ }^{33}$ loses its complexity when considering these three factors. defined sustainability as an assessment of all human behavior that is contradictory to the development of a sustainable future at an individual level, through the vision of reshaping. ${ }^{34}$

According to Brown et al. ${ }^{35}$ key components of sustainability consists of; "continuous support for human life, long-term protection of biological resource stock and agricultural systems productivity, stable human populations, limited growth economies, emphasis on self-confidence, ongoing quality in the environment and ecosystem".

The recent increase in the work on sustainability in different disciplines has increased the confusions in the terminology. published an article entitled "Examining Sustainability Terms and Their Meanings" in order to remove this complexity of cleaner production, which is an interdisciplinary subject. ${ }^{5}$ In this study, the most frequently used 41 terms and their relation to each other were considered and classified in three dimensions.

\section{Textile sector and Its environmental Impacts}

The textile and apparel sectors play a significant act a part in the economy of developing countries. This sector is the first sector of the industrialization process and it is one of the leading sectors of Turkey' s economy and constitutes $22 \%$ of export revenues. The textile sector, with approximately 2 million employees, represents Turkey's largest employment group. ${ }^{36}$

The acceleration of industrialization, the ever-increasing population of the world and the parallel reduction of clean water resources, the rapid increase in energy costs and environmental problems, the enormous sanctions of the laws related to the environment made it necessary to develop and use for environmental processes and chemicals, as it is in other sectors in the textile industry, which is at the forefront of the sectors that generate a great deal of clean water, energy consumption, and wastewater (Table 1). Along with resource consumption, the waste production also shows a rapid increase. Processes such as the adaptation of recovery in the sense of reducing environmental damage and resource consumption for ecological protection, the use of environmentally friendly fibers or other materials, the reduction of the amount of pollution and the development of methods to remove pollution afterward have become increasingly important as shown in Figure 2. ${ }^{37}$

The picture that emerges when the environmental impacts of textile materials from raw materials to use and after use are examined is very remarkable. The major environmental effects of the textile industry are the discharge of high amounts of chemical loads resulting from the high consumption of water and harmful chemicals used in this sector and the associated water pollution, ${ }^{38-40}$ high energy consumption in production processes and related air emissions, ${ }^{38,41}$ problems with packaging and solid waste production, the formation of unpleasant odors which are formed by the bleaching, dyeing and printing processes and which can arise from the wastewater treatment plant, noise pollution which occurs in places where knitting and weaving are made and causes about $80 \%$ of hearing loss in people working here. ${ }^{37}$ 
Table I Basic contaminants of textile wastewater ${ }^{92}$

\begin{tabular}{llll}
\hline $\begin{array}{l}\text { Type of } \\
\text { finished } \\
\text { textile } \\
\text { product }\end{array}$ & $\begin{array}{l}\text { Dyes, } \\
\text { g/kg } \\
\text { textile } \\
\text { product }\end{array}$ & $\begin{array}{l}\text { Auxiliaries, } \\
\text { g/kg pextile } \\
\text { product }\end{array}$ & $\begin{array}{l}\text { Basic chemical } \\
\text { compounds, } \\
\text { g/kg textile } \\
\text { product }\end{array}$ \\
\hline $\begin{array}{l}\text { Polyester } \\
\text { fibers }\end{array}$ & 18 & 129 & 126 \\
$\begin{array}{l}\text { Fabrics from } \\
\text { synthetic } \\
\text { fibers }\end{array}$ & 52 & 113 & 280 \\
$\begin{array}{l}\text { Fabrics from } \\
\text { cotton }\end{array}$ & 18 & 100 & 570 \\
$\begin{array}{l}\text { Dyed fabrics } \\
\text { from cellulose } \\
\text { fibers }\end{array}$ & 11 & 183 & 200 \\
$\begin{array}{l}\text { Printed fabrics } \\
\text { from cellulose } \\
\text { fibers }\end{array}$ & 88 & & 807 \\
\hline
\end{tabular}

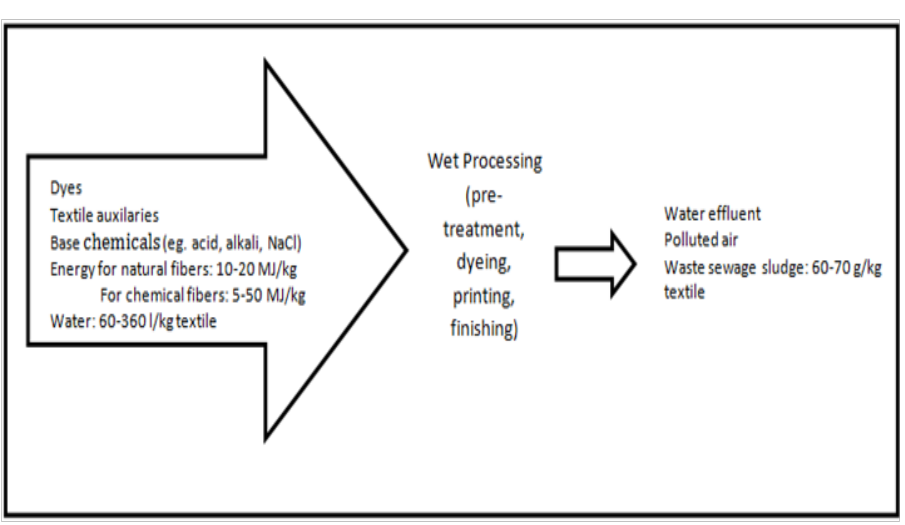

Figure 2 Environmental analysis of textile finishing processes. ${ }^{84}$

In summary, the following areas may adversely affect the sustainability of the textile industry,

i. Use of toxic chemicals

ii. Water consumption

iii. Energy consumption

iv. Waste production

v. Air emissions

vi. Transportation

vii. Packaging materials. ${ }^{42}$

\section{Chemical usage}

Since the textile industry uses high amounts of chemicals and water to form waste after processing, this sector has been convicted of pollution as one of the world's biggest criminals. ${ }^{43}$ In the textile industry, about 2000 varied chemicals are used, including dye, transfer agents etc. ${ }^{44}$ In the textile industry, about $25 \%$ of the sum chemical substances manufactured in the world are used. ${ }^{45}$

According to the World Bank estimates, dyeing and finishing operations account for $17-20 \%$ of industrial water pollution. ${ }^{46}$ Despite this, only 72 of the toxic chemical substances in the wastewater of these operations could be detected and 30 of them could not be cleaned. ${ }^{47}$

A number of the chemical substances used in textiles evaporate into the air, some of them dissolve in the wastewater discharged to the environment, and others are absorbed by human skin by clinging to the fabric. By virtue of the National Institute of Health (NIH) chemical list, some of these are used in the manufacturing of fabric and are directly connected to sanitary troubles of people. ${ }^{38}$ In accordance with a paper published in Business Week on June 5, 2005, the population with allergies to chemicals is expected to rise to $60 \%$ by $2020 .{ }^{40}$

The chemicals that cause concern when left in the environment can show subsequent characteristics, durability (not easily degraded), bioaccumulation (collect in living organisms) and poisonousness. The chemicals in this property can also be called PBTs and/ or POP's. ${ }^{38}$

It is difficult to determine the admissibility of whole chemicals which are used in the textile to be environmentally friendly. One of the reasons for these difficulties is the multiplicity of the count of dyestuffs used in coloring processes. ${ }^{38}$ The Color Index International lists 27000 products under 13000 Color Index Generic Names..$^{48}$ In the North Carolina, assessment of diverse toxicity reduction conducted between 1985 and 1995, it was explored that many chemicals related to wet treatment and recalled as toxic were recurring. ${ }^{49}$

Wastewater from the production and processing of textiles may contain high chemical oxygen demand (COD) and biological oxygen demand (BOD) values, total suspended solids (TSS), fat and grease, phosphates, sulfates, sulfides, chromium, copper and other salts of heavy metal, depending on the chemicals used and the processes applied. The most important ones are considered as COD, BOD, $\mathrm{pH}$, oils, nitrogen, phosphorus, sulphates, and SS. ${ }^{50}$ Acidic and basic compounds and metallic salts are mostly found as inorganic pollutants and their chemical and biochemical interplay in the water are different. The quality of water is reduced by these reactions. Some of the organic pollutants are biodegradable, while others are not. As biodegradable ones consume oxygen during their degradation, they decrease the water quality and influence the survival of marine organisms (Table 2 ). The organic constituents which are resistant to biodegradation part of the system for a long time and enter the food chain. The rise of these substances in the chain means that the bioaccumulation takes place and influences humans and animals. ${ }^{45}$

Desizing and wet finishing operations which have elevated COD and BOD are very important for pollution prevention and reduction. ${ }^{51}$ The most significant natural fiber used in textile is cotton and to size it starch and derivatives are often utilized. Desizing effluent of starch sized cotton fabric rise the BOD values of wastewater stream thoroughly ${ }^{45}$ and at the same time, this wastewater constitutes of circa $50 \%$ of the water contamination. ${ }^{52}$ Inherent and later attached contaminations existing on textile fibers such as oil, waxes, lubricants, etc. are expelled through scouring to refine the fibers and make it hydrophilic. Scouring of cotton is performed temperatures rising to $120^{\circ} \mathrm{C}$ in a vigorous basic solution ${ }^{45}$ and a polyester's is conducted under moderate alkaline conditions with detergents. The TDS, COD, $\mathrm{BOD}$, and alkalinity values of wastewater of scouring are very high because the contaminants are emulsified and transformed to a soluble form. ${ }^{53}$ Extremely poisonous chlorinated by-products which are caused by the use of hypochlorite, one of the earliest bleaching agents, are reduced to adsorbable organic halogens (AOX). ${ }^{52}$ Over the last decade, other agents like hydrogen peroxide $\left(\mathrm{H}_{2} \mathrm{O}_{2}\right)$ have taken the place of hypochlorite and chloride..$^{54}$ Although $\mathrm{H}_{2} \mathrm{O}_{2}$ is taken into account as an environmentally friendly choice, phosphate-based stabilizers that have to be used together it rise the COD and TOC 
content of wastewaters. If neutralization is required after the bleaching process, the quantity of salt to be released will be significant. There is a need for some chemicals to expel $\mathrm{H}_{2} \mathrm{O}_{2}$ residues remaining on the Table 2 Basic pollution sources and characteristics of textile wastewater. ${ }^{93,94}$ fabric, particularly in the reactive dyeing, since it speeds up hydrolysis of the dye (Table 3$).^{45}$

\begin{tabular}{|c|c|c|c|c|c|c|c|c|}
\hline \multirow[t]{2}{*}{ Processes } & \multirow[t]{2}{*}{ Possible pollutants } & \multicolumn{7}{|c|}{$\begin{array}{l}\text { Nature of effluent (from finishing processes of cotton } \\
\text { fabric) }\end{array}$} \\
\hline & & $\begin{array}{l}\mathrm{COD}\left(\mathrm{gO}_{2} / \mathrm{l}\right) \\
\text { Usage }\end{array}$ & $\begin{array}{l}\mathrm{BOD} \\
\left(\mathrm{gO}_{2} / \mathrm{I}\right)\end{array}$ & TS $(g / l)$ & TDS (g/l) & $\mathrm{pH}$ & $\begin{array}{l}\text { Color } \\
\text { (ADMI) }\end{array}$ & Water \\
\hline Desizing & $\begin{array}{l}\text { Starch, glucose, PVA, } \\
\text { resins, fats, waxes }\end{array}$ & $4.6-5.9$ & $1.7-5.2$ & $16-32$ & - & - & - & 9-Mar \\
\hline Scouring & $\begin{array}{l}\text { Caustic soda, waxes, soda } \\
\text { ash, sodium silicate and } \\
\text { fragments of cloth }\end{array}$ & 8 & $0.1-2.9$ & $7.6-17.4$ & - & $13-O c t$ & 694 & $26-43$ \\
\hline Bleaching & $\begin{array}{l}\text { Hypochlorite, chlorine, } \\
\text { caustic soda, hydrogen } \\
\text { peroxide, acids }\end{array}$ & $6.7-13.5$ & $0.1-1.7$ & $2.3-14.4$ & $4.8-19.5$ & $8.5-9.6$ & 153 & $3-124$ \\
\hline Mercerising & Caustic soda & 1.6 & $0.05-0.1$ & $0.6-1.9$ & $4.3-4.6$ & $5.5-9.5$ & - & $232-308$ \\
\hline Dyeing & $\begin{array}{l}\text { Dye stuff, mordant and } \\
\text { reducing agents like } \\
\text { sulphides, acetic acids } \\
\text { and soap }\end{array}$ & I.I-4.6 & $0.01-1.8$ & $0.5-14.1$ & 0.05 & I0-May & $1450-4750$ & $8-300$ \\
\hline
\end{tabular}

Table 3 Environmentally friendly chemical choice for wet textile processing. ${ }^{95}$

\begin{tabular}{|c|c|c|}
\hline Purpose & Chemical & Alternative \\
\hline Sizing & Starch & Water-soluble PVA \\
\hline Desizing & $\begin{array}{l}\text { Hydrochloric } \\
\text { acid }\end{array}$ & Amylases \\
\hline Scouring of cotton & $\begin{array}{l}\text { Sodium } \\
\text { hydroxide }\end{array}$ & Pectinases \\
\hline Bleaching & Hypochlorites & Hydrogen peroxide \\
\hline $\begin{array}{l}\text { Oxidation of vat and } \\
\text { sulphur dyes }\end{array}$ & $\begin{array}{l}\text { Potassium } \\
\text { dichromate }\end{array}$ & $\begin{array}{l}\text { Hydrogen peroxide, } \\
\text { sodium perborate }\end{array}$ \\
\hline Thickener & Kerosene & $\begin{array}{l}\text { Water-based polyacrylate } \\
\text { copolymers }\end{array}$ \\
\hline Hydrotropic agent & Urea & Dicyanamide (partially) \\
\hline Water repellents & $\begin{array}{l}\text { C8 } \\
\text { fluorocarbons }\end{array}$ & C6 fluorocarbons \\
\hline $\begin{array}{l}\text { Crease recovery } \\
\text { chemicals }\end{array}$ & $\begin{array}{l}\text { Formaldehyde- } \\
\text { based resin }\end{array}$ & Polycarboxylic acid \\
\hline $\begin{array}{l}\text { Wetting agents and } \\
\text { detergents }\end{array}$ & $\begin{array}{l}\text { Alkyl phenol } \\
\text { ethoxylates }\end{array}$ & $\begin{array}{l}\text { Fatty alcohol phenol } \\
\text { ethoxylates }\end{array}$ \\
\hline Neutralization agent & Acetic acid & Formic acid \\
\hline Peroxide killer & $\begin{array}{l}\text { Sodium } \\
\text { thiosulphate }\end{array}$ & Cataleses \\
\hline Mercerization & $\begin{array}{l}\text { Sodium } \\
\text { hydroxide }\end{array}$ & Liquid ammonia \\
\hline Reducing agents & Sodium sulphide & $\begin{array}{l}\text { Glucose, acetyl acetone, } \\
\text { thiourea dioxide }\end{array}$ \\
\hline Dyeing & $\begin{array}{l}\text { Powder form of } \\
\text { sulphur dyes }\end{array}$ & Pre-reduced dyes \\
\hline Flame retardant & $\begin{array}{l}\text { Bromated } \\
\text { diphenyl ethers }\end{array}$ & $\begin{array}{l}\text { Combination of inorganic } \\
\text { salts and phosphonates }\end{array}$ \\
\hline Shrink proofing & Chlorination & Plasma treatment \\
\hline
\end{tabular}

Because of the ability of sulfates flair to constitute vigorous acids, they cause $\mathrm{pH}$ alterations in the environment where they are present, while the phosphates also cause eutrophication in the water, so these two are poisonous in high concentrations. ${ }^{38}$

There are always apprehensions about environment throughout the dyeing process. They can be reduced awaring their resources and taking suitable precautions. According to Shukla ${ }^{55}$ they can be categorized,

a. Textile raw fibres may be contaminated with polluting chemicals.

b. Dyes contain pollutants and hazardous materials.

c. Auxiliary chemicals may have their own impact.

d. Dyeing operations are water-intensive leading to large volumes of effluent.

e. As far as possible recycling, reuse of the dyestuffs and chemicals should be practised.

f. Implement overall best management practices.

Commercial dyes active substances are generally changing 20$80 \%$. Dyes may include contaminants and hazardous substances such as nickel, copper, heavy metals, etc. and they are poisonous to marine organisms. Although they are present in small quantities in the majority of the dyes, they are extremely dangerous because of their biodegradation resistance and propensity to pile up at elevated concentrations..$^{55}$

Some textile auxiliaries are used in almost all stages of textile, despite adverse environmental effects. Alkyl phenol ethoxylates (APEOs) are largely utilized as detergent and wetting agent especially in scouring and bleaching stages. Their hormone-disruptive, nonbiodegradable so highly durable properties bring about wastewater treatment troubles. ${ }^{45} \mathrm{NPs}$ and nonylphenol ethoxylates usage are limited also in the EU because of their adverse impacts on mankind and surrounding. ${ }^{56}$ Non-ionic surfactants pose a special trouble. 
Because of their slow degradation, they cause toxic effects. Knowing the biodegradability grades is an important factor in waste treatment. There are two alternatives for slow degrading materials, either longer processing or substitution with faster separable ones. It is predicted there are over than 500 various ionic group-free surfactants in textiles and the environmental data about these compounds are inadequate.

Sodium chloride/sulphate, in the direct and reactive dyeing of cotton utilized as exhausting agents, also pose a particular problem. There is still no applicable procedure to eliminate these salts from the textile effluent, up to the present, the only way to get rid of this problem is to dilute the wastewater. However, the problem is trying to be decreased by using poly-reactive dyes or impregnation processes with lower salt needs. Many blue and black colors have copper which free state acts as a toxic agent. For this reason, their display and the development of copper-free paints have been supported. ${ }^{38}$

Formaldehyde is commonly used in the synthesis of stabilizer in the reactive and direct dyeing, and dispersants in the vat and disperse dyeing. It causes skin irritation and the respiratory system. These adverse effects require the release of formaldehyde-based products or replacement with formaldehyde-free products. ${ }^{57}$

Preventing the use of sulfide in reducing the dyes is another important consideration. It is recommended to use polymer or mechanically stabilized sodium hydrosulfite instead of compounds containing aldehydes and toxic metals. Preferring water-based systems for solvents and dispersants in place of halogenated ones is an another environmental approach. Substituting urea which is a dyebath auxiliary as much as feasible, replacing EDTA by NTA, usage of decarbonated water in temperature and $\mathrm{pH}$ controlled dyeing bath to decrease the usage of textile auxiliaries, eliminating usage of a carrier by preferring HT dyeing are more environment and human beings sensitive changes. The use of retarders and levelers, which are used as auxiliary chemicals in the dyeing of nylon fibers, can be eliminated by performing $\mathrm{pH}$ and temperature controlled dyeing. The use of retarder, the primary auxiliary chemical in the dyeing of acrylic fibers, can be eliminated by controlled dyeing of the rate of temperature rise. ${ }^{55}$

With the finishing processes, textiles are given various functionalities. Formaldehyde has been broadly utilized as a fixing agent, softener, and cross-linking resin. During use of such textile products can provoke eye irritation, itching of skin and allergy because of releasing formaldehyde. ${ }^{45}$ Perfluoroalkyl chains which have eight or more fluorinated carbons are used to get resistant effects of oil stain, and water repellency in textile goods. ${ }^{58}$ When this long chain polymer is degraded and perfluoro octane sulphonate (PFOS) and perfluorooctanoic acid (PFOA) occur. They have toxicological features for whole the living. ${ }^{59}$ Many of finishing chemicals used to give flame-retardant property have been found to be very toxic to humans, like polybrominated diphenyl ethers (PBDEs). ${ }^{60}$

After some certain toxic compounds have been eliminated, a wide range of chemical groups, called auxiliary chemicals for textiles, remain. These "brand products" consist of a blend of surfactants, softeners, solvents, chelates and water-based polymers, many of which are blends projected to fulfill a specific duty throughout all textile stages. The broad diversity of different chemical concentrations that can be used in these products present important hassles in detecting the constituent of these blends and are also an exaggerated problem, as producers keep the contents as a professional secret. ${ }^{38}$

\section{Water consumption}

Fresh water is a resource that is getting limited every day.
Currently, approximately five hundred millions people maintain their lives in areas incline to lack of water and it is anticipated that by 2025 this figure will be five times that between $50-75 \%$ of the world's population in Figure 3. ${ }^{40}$

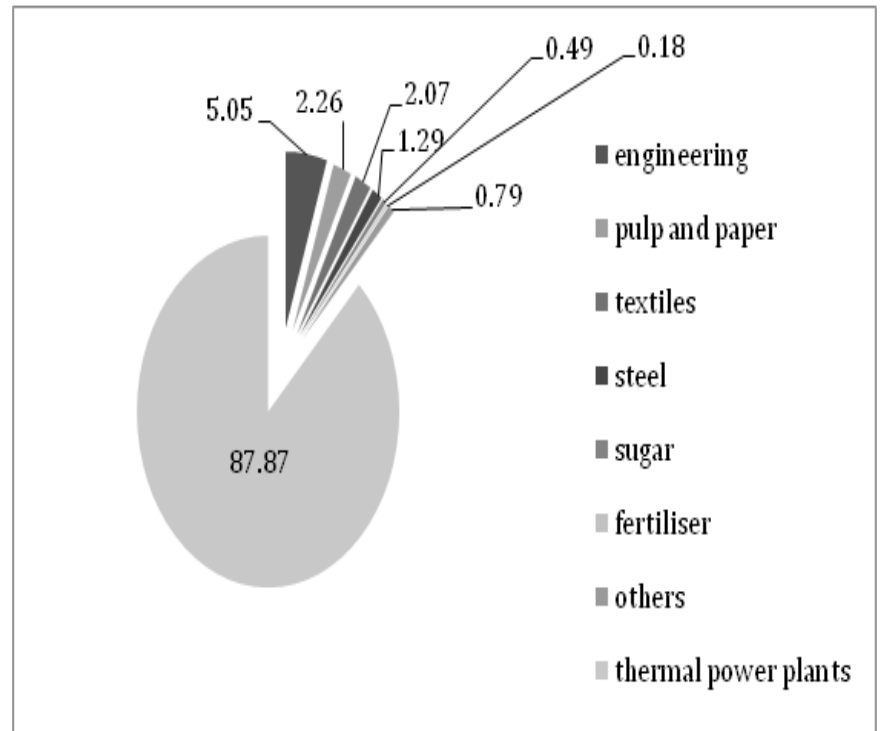

Figure 3 Water consumption by various sectors. ${ }^{98}$

In the textile industry, used water is in each stage of the wet finishings to transport chemicals to textiles and to be washed the material before moving to the next step. Apart from these processes in textiles, there is also water consumption during cooling water, boiler, steam drying and cleaning. ${ }^{61}$ Average water spending of a medium sized textile factory producing around $8,000 \mathrm{~kg}$ fabric/day is 1,6 million liters, approximately. Of these, $16 \%$ are spent in dyeing and half of it is consumed in printing. Depending on the dye used in the dyeing, 30-50 liters of water per kilogram of fabric is consumed in Figure 3. Totally, during yarn dyeing, about 60 liters of water is spent per kg of yarn. Wastewater released during the dyeing process constitutes about $1 / 5$ of total wastewater. To obtain the required fastness values and to clean the machines, water is needed, too. The amount of water spent for fabric manufactured to cover a sofa is about 500 gallons. ${ }^{47}$ During conventional dyeing and finishing processes of $1000 \mathrm{kgs}$ of fabric, about two hundred thousand kilograms of water is contaminated and in these stages, a great deal of steam and hot water is consumed for energy ${ }^{62}$ To produce a cotton shirt, about 2,500-3,000 1 of water is consumed. The majority of this water is spent during the cultivation of cotton, while the amount spent on wet textile processing is in the second place ${ }^{63}$ (Table 4).

Textiles, one of the most intensive industries in terms of chemical use is the textile and it is the first number of pollutant after agriculture for clean water. ${ }^{40}$

The Textile Industry is forced to think about water saving because of many reasons, mentioned above. Because of industrial and residential expansion, reduction of water tables and sources of clean water, rivalry for clean water rises. Generally, costs of water and waste can constitute $5 \%$ of manufacture costs. ${ }^{61}$

The initial results of water and wastewater problems have begun to be felt in textile treatments. In China and India, for example, new companies do not receive grant support unless they offer a case that convinces them that they will help solve water consumption and wastewater problems. ${ }^{63}$ Nowadays, in the textile, protection and reuse of water is getting essential rapidly and they can have huge advantages 
through reduced charge of purchased water, by this way decreasing in production costs, decreases the price for wastewater treating, and avoiding from discharging infringement. Water conservation measures lead to an also reduction in thermal and electrical energy consumption. ${ }^{61}$

Table 4 The amount of water spent and organic loading in diverse sections of a textile plant. ${ }^{92}$

\begin{tabular}{lllllll}
\hline $\begin{array}{l}\text { Operation/ } \\
\text { process }\end{array}$ & \multicolumn{3}{l}{$\begin{array}{l}\text { Water consumption (\% from total } \\
\text { consumption of the textile plant) }\end{array}$} & \multicolumn{3}{l}{$\begin{array}{l}\text { Organic load (\% from total organic load } \\
\text { of the textile plant) }\end{array}$} \\
\cline { 2 - 7 } & Minimum & Medium & Maximum & Minimum & Medium & Maximum \\
\hline General facilities & 6 & 14 & 33 & 0.1 & 2 & 8 \\
Preparation & 16 & 36 & 54 & 45 & 61 & 77 \\
Dyeing & 4 & 29 & 53 & 4 & 23 & 47 \\
Printing & 42 & 55 & 38 & 42 & 59 & 75 \\
Wetting & 0.3 & 0.4 & 0.6 & 0 & 0.1 & 0.1 \\
Fabric washing & 3 & 28 & 52 & 1 & 13 & 25 \\
Finishing & 0.3 & 2 & 4 & 0.1 & 3 & 7 \\
\hline
\end{tabular}

According to ${ }^{61}$ water conservation methods for textile mills are; use of automatic shut-off valves, flow control valves, low material to liquor ratio systems, flocculation of clean water of pigment printing, use single stage of processing, water conservation measures in dyeing equipment and good housekeeping.

Reuse of wastewater can provide significant savings, such as reducing water, energy and chemical consumption. Condensed steam and cooling water which are clean can be easily recovered and their thermal power recovery improves return on investment. ${ }^{38}$

\section{Energy consumption}

In addition to a huge amount of water and chemical consumption, textile treatments consume a great deal of energy to heat, dry and operate the machines which cause with going up the greenhouse gasses emission and the carbon footprints. ${ }^{45}$ These cases are due to the long and complex structure of the textile. ${ }^{64}$ It is estimated that the annual textile production in 2008 is 60 billion kilograms of fabric, and 1.074billion kWh of electricity and 6-9 trillion liters of water are necessary to produce it. ${ }^{63}$ It has been reported that for manufacturing and consumer use, the total thermal and electric energy necessities are 18.8-23 MJ and 0.45-0.55kWh per meter of fabric, respectively. ${ }^{41}$

Various types of energy are needed in the textile for the operation of the machines and the execution of the processes, for the climate conditioning and illumination of the environment in which the production is to be realized. Electricity is the main energy source of chilling, controlling of temperature, lighting and office equipment in machinery and textile industry ${ }^{45}$ The yam and cloth manufacturing processes are the main usage of electrical energy in the textile industry and amounting to nearly $3 / 4$ or $4 / 5$ of the total energy need in a textile mill, whereas scarcely 15 to $20 \%$ of electrical power is spent for running various machines in textile wet processing (Table 5). ${ }^{65}$

In order to produce steam; fuel, LPG, coal and city gas are commonly utilized. Except for little quantity of energy required to operate the machinery of textile, mostly needed energy for chemical processes is thermal and it is generally provided by steam. The greenhouse gasses which are come out after incineration of fossil fuels is used to generate steam (Table 5). This situation makes a contribution to carbon footprints of textiles, primarily. For that reason, to decrease it, the great potential is found in the usage of renewable energy. ${ }^{45}$
Table 5 Energy consumption share of each specialized technical field in the textile industry. ${ }^{65}$

\begin{tabular}{lllll}
\hline $\begin{array}{l}\text { Specialized } \\
\text { technical field }\end{array}$ & Fuel & Electricity & Total & Share \% \\
\hline Fiber production & 32.551 & 21.498 & 54.049 & 21 \\
Spinning & 3.224 & 44.262 & 47.48 & 18.4 \\
$\begin{array}{l}\text { Twisting } \\
\text { Textured yarn }\end{array}$ & 219 & 1.66 & 1.879 & 0.7 \\
production & 120 & 1.543 & 1.663 & 0.6 \\
$\begin{array}{l}\text { Weaving } \\
\text { Knitting }\end{array}$ & 4.467 & 24.848 & 29.315 & 43 \\
$\begin{array}{l}\text { Dyeing } \\
\text { Clothing }\end{array}$ & 3.059 & 11.709 & 15.858 & 6.1 \\
manufacturing & 8.24 & 15.42 & 23.66 & 9.2 \\
Others & 5.959 & 12 & 17.959 & 7 \\
Total & 96.5 & 161.44 & $\mathbf{2 5 7 . 9 4 2}$ & 100 \\
\hline
\end{tabular}

Thermal energy is dominant in the chemical treatment process, predominantly used to heat water and dry textile materials, while spinning and weaving are dominated by electricity energy in energy consumption patterns in Figure 4. ${ }^{66}$

Textile is one of the sectors that produce greenhouse gasses in maximum amounts. Indirect carbon footprints of textiles, ${ }^{45}$ 'embedded energy' inside the goods, which is totally used energy in the manufacturing process, is important to define the carbon footprint of any goods. ${ }^{42}$ The carbon footprint of a textile commodity depends on raw material type and its processing. When the contributions of the cotton textiles treated in the continuous system to the process-based emission are examined about half of the total emission comes from drying, $40 \%$ and $10 \%$ come from washing, steaming and chemical usage, respectively. For knitwear finishing process emission caused from heating the water in exhaust process. ${ }^{67}$

In spite of the chemical processing energy requirement is only about $38 \%$ of the total textile production energy need, ${ }^{65}$ usage of energy is very inefficient. ${ }^{45}$ Between 1990 and 2005, productivity jute fiber products, raw fabric, and polyester chips increased and their 
carbon emission densities decreased by about $2.07,1.90$, and $0.72 \%$, in turn. Whereas in cotton yarn the opposite is true, i.e. the density of emission has risen by about $7.37 \%$, that shows that cotton thread production is inefficient in Figure 4. ${ }^{38}$

Protection of the energy is an inevitable stage to tackle the problems of the global environmental deterioration and emergency of energy. The energy can be conserved via modifying of processes, machinery, and chemical prescriptions and using of recent technologies. Dissipation of heat through machinery which running at high temperatures and poorly maintained steam pipes lead to energy loss. Convenient isolation ensures reluctance to convectional heat transfer from machines and pipes to ambient air via lesser spending of vapor and fuel. Moreover, insulation lessens the risk of burns by decreasing the outer surface temperatures and make more comfortable the working environment. ${ }^{45}$
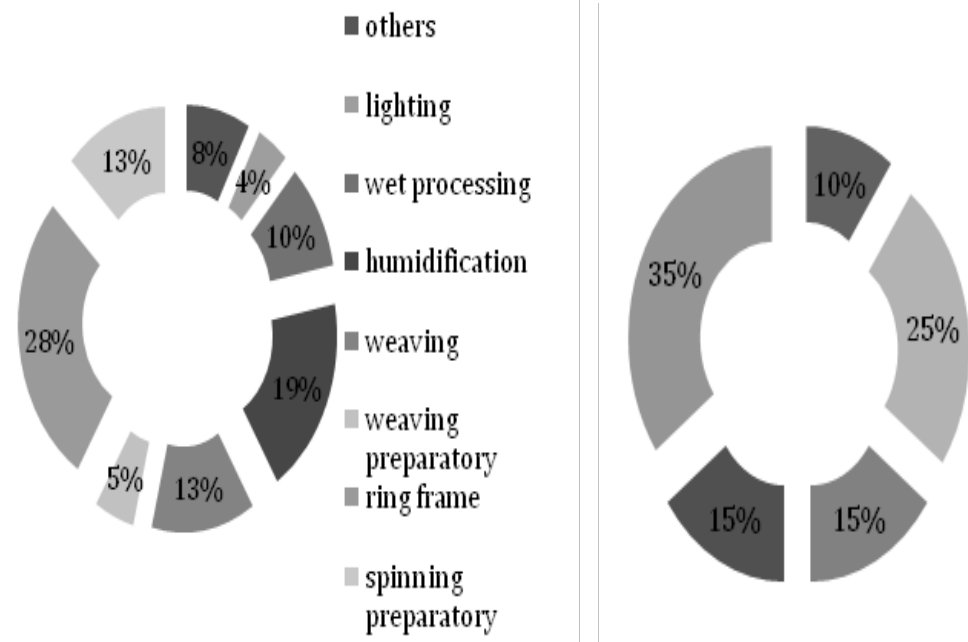

- steam
distribution
network losses
boiler plant losses

uumidification, si
zing and others
dyeing and
printing
consumption
bleaching and
finishing
consumption

Figure 4 Distribution of electricity and thermal energy expenditures in integrated textile enterprises ${ }^{66}$

\section{Waste generation}

As in other industries, the textile industry also produces wastes in all forms, such as liquid, solid and gaseous. Fast-fashion, falling prices and disposable clothing cause producing about $31 \mathrm{kgs}$ waste of clothing and textile in a one year per person in America ${ }^{68}$ The results are similar in England. ${ }^{69}$ Although textile products are 100\% recyclable,$^{70}$ textile recycling rates are about $15 \%$ even in developed countries like the US. ${ }^{71}$ Most textile wastes, unfortunately, go to landfills, and about $80 \%$ of these are synthetic, and the rest is natural fibers $^{72}$ (Table 6).

Current waste management of textile products is incineration for energy recovery, reuse, and recycling. In the market, a number of varied technologies are available or being developed for the recycling of waste of textiles. ${ }^{73}$ One of these is mechanical recycling, and the SOEX (SOEXGROUP) ${ }^{74}$ transforms 15,000tons of clothing per year in 10 different countries into insulation materials for construction and automobiles. Teijin Fibre Ltd. is cooperating with Patagonia Inc. to obtain granules from $100 \%$ polyester fabrics and decomposes these with a chemical reaction to obtain DMT and it used to get PET granules again with a repolymerization. ${ }^{75}$

One of the new technologies developed for textile waste management is a process in which viscose fibers from waste cellulosic textiles are produced by the Swedish Re,NewCell company. In this process, the cellulosic portion of the textile material is discreted by solubilising in an alkaline liquor and then filtered to manufacture the viscose fiber. There is little information about this process that is still developing. ${ }^{76}$ In an another technology, it has been offered that the disintegration and recycling of cellulose based and synthetic fibers via $\mathrm{N}$-methyl-morpholine-N-oxide can be further improved. Steps of this technique are blending the mixture with $\mathrm{N}$-methyl-morpholine$\mathrm{N}$-oxide, filtering the solution to separate polyester and cellulose fractions which dissolve in the solution, reusing the filtered polyester- containing solution to produce polyester fibers. ${ }^{77}$

Ashes and mud, carton box, film, non-recyclable dirty fabric, plastic bags, non-reusable goods like paper cones and tubes are solid wastes from textile production, also. ${ }^{38}$

The high amount of $\mathrm{NaOH}$ used in the mercerization bath can be recovered by heating the solution and this can be given as an example of chemical recovery. ${ }^{78}$ This process can provide $90 \%$ of sodium hydroxide recovering. The EVAC vacuum suction system helps to recover of hot alkaline hydrogen peroxide, textile auxiliaries and finishing chemicals in the chemical processes. ${ }^{79}$ Chieng Sang Industry Co. has established it in order to suck up excess water remaining on the fabric after the finishing process to reuse in an another process. ${ }^{80}$ (Table 6).

Degradation of the polyvinyl alcohol (PVA) in a textile plant poses challenges for sources because of its significant COD contribution to wastewater and non-compostable structure. There is no effective way to treat wastewater containing PVA. Although ultrafiltration (UF) reverse osmosis (RO) technology has been used 35 years for recovery and recycling of PVA size, it can not be used extensively due to its lots of disadvantages. This shows that PVA needs a new technology that can reduce energy and water consumption for recycling and recovering. VFE (vacuum flash evaporation) is a new technology and it can remove the disadvantages of UF, but it has not still found a place in the recovery of PVA desizing process. ${ }^{81}$

\section{Air emissions}

Air and water pollutants affect the world with varied weather events and spending amount of soiled nutrition goods. ${ }^{45}$ Pollution of air is the chemical substances, particles or biological materials that induce damage or disturbance to human beings or the other creatures penetration into the atmosphere. ${ }^{82}$ 
It is known that data about emissions of air belong to textile processes are not easily accessible, but many processes in textile cause air emissions. The secondary important pollutant in the textile after waste disposal is the emission of gas. Air emissions include dust and lint, oil fumes, acid vapor, solvent mists, odor and boiler exhausts. ${ }^{83}$ If textile materials contain oil, plasticizers and other materials, they degrade when exposed to high temperatures, and forms fog. The stenter frame is the most common source of it. Formaldehyde also called methanal, and acetic acid are important emission sources, too. During wool carbonization, corrosive acid fumes are generated and volatilization of acids occur. Solvent vapors which include toxic

Table 6 Summary of textile wastes produced during textile production. ${ }^{96}$ chemicals such as kerosene or mineral turpentine oil, formaldehyde, chlorofluorohydrocarbons, mono- and dichlorobenzene, ethyl acetate, hexane, styrene etc. come up after dyeing and printing processes. Oil mists or solvent vapors connect with odor. For example, carriers used for polyester dyeing, dye reduction in sulfur dyeing of cotton with hydrosulphite and bleaching with sodium hypochlorite cause odor. Dust and lints are generated prior to processing of natural and synthetic fibers and through their spinning, napping, carpet shearing processes. Their inhalation cause many respiratory sicknesses ${ }^{84}$ (Table 7) (Table 8).

\begin{tabular}{|c|c|c|c|}
\hline Process & Emission & Wastewater & Solid wastes \\
\hline $\begin{array}{l}\text { Fiber } \\
\text { preparation }\end{array}$ & Little/none & Little/none & Fiber waste and packaging waste \\
\hline Yarn spinning & Little/none & Little/none & $\begin{array}{l}\text { Packaging wastes, sized yarn, fiber } \\
\text { waste,cleaning and processing waste }\end{array}$ \\
\hline Slashing/sizing & VOCs & BOD, COD, metals, cleaning waste, size & $\begin{array}{l}\text { Fiber lint, yarn waste, packaging waste, } \\
\text { unused starch-based sizes }\end{array}$ \\
\hline Weaving & Little/none & Little/none & $\begin{array}{l}\text { Packaging waste, yarn and fabric scraps, } \\
\text { off-spec fabric, used oil }\end{array}$ \\
\hline Knitting & Little/none & Little/none & $\begin{array}{l}\text { Packaging waste, yarn and fabric scraps, } \\
\text { off-spec fabric }\end{array}$ \\
\hline Tufting & Little/none & Little/none & $\begin{array}{l}\text { Packaging waste, yarn and fabric scraps, } \\
\text { off-spec fabric }\end{array}$ \\
\hline Desizing & VOCs from glycol ethers & $\begin{array}{l}\text { BOD from sizes lubricants, biocides, anti-static } \\
\text { compounds }\end{array}$ & $\begin{array}{l}\text { Packaging waste, fiber lint, yarn waste, } \\
\text { cleaning and maintenance materials }\end{array}$ \\
\hline Scouring & $\begin{array}{l}\text { VOCs from glycol ethers } \\
\text { and scouring solvents }\end{array}$ & $\begin{array}{l}\text { Disinfectants, insecticide residues, } \mathrm{NaOH} \text {, detergents, } \\
\text { oils, knitting lubricants, spin finishes, spent solvents }\end{array}$ & Little/none \\
\hline Bleaching & Little/none & $\mathrm{H} 2 \mathrm{O} 2$, stabilizers, high pH & Little/none \\
\hline Singeing & $\begin{array}{l}\text { Small amounts of } \\
\text { exhaust gases from the } \\
\text { burners exhaustic which } \\
\text { components }\end{array}$ & Little/none & Little/none \\
\hline Mercerising & Little/none & High $\mathrm{pH}, \mathrm{NaOH}$ & Little/none \\
\hline Heatsetting & $\begin{array}{l}\text { Volatilisation of spin finish } \\
\text { agents-synthetic fiber } \\
\text { manufacture }\end{array}$ & Little/none & Little/none \\
\hline Dyeing & VOCs & $\begin{array}{l}\text { Metals, salt, surfactants, organic processing assistants, } \\
\text { cationic materials, color, BOD, COD, sulphide, acidity/ } \\
\text { alkalinity, spent solvents }\end{array}$ & Little/none \\
\hline Printing & $\begin{array}{l}\text { Solvents, acetic acid- } \\
\text { drying and curing oven } \\
\text { emissions combustion, } \\
\text { gases }\end{array}$ & $\begin{array}{l}\text { Suspended solids, urea, solvents, color, metals, heat, } \\
\text { BOD, foam }\end{array}$ & Little/none \\
\hline Finishing & $\begin{array}{l}\text { VOCs, contaminants in } \\
\text { purchased chemicals, } \\
\text { formaldehyde vapors, } \\
\text { combustion gases }\end{array}$ & COD, suspended solids, toxic materials, spent solvents & $\begin{array}{l}\text { Fabric scraps and trimmings, packaging } \\
\text { waste }\end{array}$ \\
\hline
\end{tabular}


At the forefront of environmental problems are greenhouse gas emissions that pose a threat to all living things due to the effect on climate. Burning fossil fuels significantly increases the amount of carbon dioxide emissions, which is the primary source of the greenhouse effect. ${ }^{38}$

In textile enterprises, sulfur and nitrogen oxides usually emerge due to the boilers. These oxides disrupt the $\mathrm{pH}$ balance of habitats, damaging living organisms and also cause degradation of metal artifacts. The other important air emission sources in textile processing Table 7 Air emissions released from different textile processes. ${ }^{82}$ are anti-crease finishing, drying, printing, dyeing and wastewater treatment facilities. These processes dissipate hydrocarbons which released from mineral oils during drying and curing processes which are performed at high temperature, acids, formaldehyde, softeners, and other evaporating compounds. ${ }^{82}$ Remnants from the fiber preparation process sometimes can cause emissions during thermal fixation. ${ }^{85}$

For this reason, all of the stakeholders in this industry must gather to support for maintaining of sustainability.

\begin{tabular}{|c|c|c|}
\hline Process & Sources & Pollutants \\
\hline Energy production & Emissions from boiler & Particulates, NOx, SO2 \\
\hline Coating, drying, curing & Emissions from high temperature ovens & Volatile organic components \\
\hline Cotton handling activities & $\begin{array}{l}\text { Emissions from preperation, carding, combing, fabric } \\
\text { manufacturing }\end{array}$ & Particulates \\
\hline Sizing & Emissions from using sizing compound & $\begin{array}{l}\text { Nitrogen oxides, sulphur oxide, carbon } \\
\text { monoxide }\end{array}$ \\
\hline Bleaching & Emissions from using chlorine compound & Chlorine, chlorine dioxide \\
\hline Dyeing & $\begin{array}{l}\text { Disperse dyeing using carriers, sulphur dyeing aniline } \\
\text { dyeing }\end{array}$ & Carriers, $\mathrm{H} 2 \mathrm{~S}$, Aniline vapors \\
\hline Printing & Emissions & Hydrocarbons, ammonia \\
\hline Finishing & Resin finishing, heat setting of synthetic fabrics & $\begin{array}{l}\text { Formaldehyde, carriers, polymers-lubricating } \\
\text { oils }\end{array}$ \\
\hline Chemical storage & $\begin{array}{l}\text { Emissions from storage tanks for commodity and } \\
\text { chemicals }\end{array}$ & VOCs \\
\hline Waste water treatment & Emissions from treatment tanks and vessels & VOCs, toxic emissions \\
\hline
\end{tabular}

Table 8 Effect of pollutants on human beings. ${ }^{82}$

\begin{tabular}{lll}
\hline Pollutants & Effects on human beings & Sources \\
\hline Sulphur di oxide & Irritates respiratory system and causes bronchitis & Boiler flue gas, rayon plant etc. \\
Aldehydes & Irritates all parts of respiratory system & Polyester plant \\
Chlorine & Causes lung irritation and also irritation in eyes & Processing house \\
Carbon di oxide & $\begin{array}{l}\text { Deprives body cells of oxygen and cause unconsciousness by CO } \\
\text { combining with haemoglobin }\end{array}$ & Boiler house \\
\hline
\end{tabular}

\section{Transportation}

Textile and ready-to-wear sector consist of a long and complex manufacturing stages such as manufacturing source, fiber production, coloring and finishing treatments, mounting of apparel, packaging, carrying, recycling and/or final eradication. ${ }^{86}$

Life-Cycle Inventory (LCI) is an essential ingredient of LCA. Data of emissions, materials, and energy inputs connected with all manufacturing and usage stages of goods are defined numerically in this way. The LCI include data about the carriage, readymade, and disposal, also. Carriage of an intermediate product such as raw cotton transportation to the spinning mill, treated fabric from finishing mill to cut-and-sew and after to customer take part in transportation. ${ }^{87}$ The transportation increases the total amount of consumed non-renewable fuel..$^{38}$ Namely, this means that it contributes to global warming by $\mathrm{CO}_{2}$ emission.

The Higg Index, the core of the Sustainable Clothing Coalition, allows trademarks, retail dealers and mills to evaluate their ecological and communal and labor effects and to specify fields that need recuperation.$^{88}$ This index also covers the whole life span of a goods, containing from raw materials to bundling, carriage, user utilization and end-of-life. ${ }^{89}$

\section{Packaging materials}

The packaging process has five main purposes. The first aim is to protect the product against any damage that may occur during transportation and storage. The second aim is to assemble the products. The third one is to transfer the information which is about to usage, disposing and transporting of the product. Marketing and preventing the theft of products are the fourth and fifth one, respectively. ${ }^{90}$

During other textile processes like spinning, fabric manufacturing, dyeing etc., in packaging various sources like energy and chemicals are used. Today's packaging substances are usually produced from petroleum-based materials. Recently, the packaging area has faced strict rules on the reuse and recycling. The Directive 94/62/EC on "Packing and Packaging Waste", which is being implemented in the EU, has forced many package types to be observed. This directive remarks a series of necessaries for packaging and it's trashes. At the 
same time, it sets maximum levels for recycling targets and heavy metals. Companies carrying out environmentally friendly actions are seeking to reduce their carbon footprint by using packaging material which obtained from recycled and compostable stuff, natural goods are produced without any chemicals like pesticides. ${ }^{38}$ In clothing process $2.472 \mathrm{MJ}$ energy is consumed; $49.8 \%$ used in sewing, $29.6 \%$ in cutting, and $20.6 \%$ in packaging. ${ }^{91-98}$

\section{Conclusion}

Sustainability is much more than a trending word at a certain time. The three key elements of sustainability are; economic and social development, environmental protection, and each one each one should be considered in relation to the others. Sustainability is very crucial because it maintains people quality of life with protecting diversity and ecosystems in the world with various ways; protecting natural resources, providing energy savings, decreasing waste quantity, investment in the future and economy with recycling/reusing. Namely, it ensures the existence of species. A contemporary and secure business environment is created by respecting human rights, securing the social justice and protecting the working rights within the scope of sustainability. Cleaner production is not just a buzzword, but also one of the basic approaches to sustainability. It is a systematic approach that involves identifying pollution-causing processes and technologies that lead to the inefficient utilize of energy and raw materials, revealing points that need improvement, and implementing cleaner production opportunities.

There are international organizations and institutes around the world to ensure cleaner production and therefore sustainability. The policies pursued in these institutions are generally European Union environmental policies, but various tools can be used depending on the application areas of cleaner production. The policies pursued in these institutions are generally european Union environmental policies. On the basis of their own domestic regulations, the European Union (EU) promote the adoption of stringent environmental policies at the international level with legislations based on different issues. The EU is also leading the shaping of policies about the environment in non-member countries. The choice of which tools are used to determine the use of cleaner production opportunities according to their application areas depends on the problem in operation and the work to be done.

The lifelong ecological impacts of textile products are affected by the raw materials, their origin and the durability of the product, in addition to the production methods. The picture that emerges when the use of textile products from raw materials and their subsequent environmental effects are very striking because of their chemical, energy, water usage, packaging and solid waste production, the formation of unpleasant odors and noise pollution. Increased textile consumption due to improvements in the world population and improvements in living standards along with the environmental effects of the textile, require the improvement of the environmental performance of this industry. In this sense, the concept of sustainability has become a matter of concern in the textile sector.

\section{Acknowledgements}

As editors of this paper, we would like to thank all reviewers for their indispensable contributions.

\section{Conflict of interest}

Author declares there is no conflict of interest in publishing the article.

\section{References}

1. Büyükaslan E, Jevšnık S, Kalaoglu F. A Sustainable Approach to Collect Post-Consumer Textile Waste in Developing Countries. Marmara Fen Bilimleri Dergisi. 2015;27:107-111.

2. United States Environmental Protection Agency (US EPA). Municipal Solid Waste Generation, Recycling, and Disposal in the United States: Facts and Figures for 2010. US EPA; 2010. p. 13.

3. Environmental Hazards of the Textile Industry. Textile Industry Poses Environmental Hazards. Hazardous Substance Research Center, Ecotextiles, 2005. p. 4.

4. Reddy BS, Ray BK. Understanding Industrial Energy Use: Physical Energy Intensity Changes in Indian Manufacturing Sector. Energy Policy. 2011;39:7234-7243.

5. Arputharaj A, Raja ASM, Saxena S. Developments in sustainable chemical processing of textiles. Green Fashion, 2015. p. 217-252.

6. Hawley J. Textile Recycling Options: Exploring what could be. Eartscan, London, UK; 2011.

7. Sherburne A. Achieving sustainable textiles: a designer's perspective. Oxford: Woodhead Publishing; 2009.

8. Carmen Z, Daniela S. Textile organic dyes-characteristics, polluting effects and separation/elimination procedures from industrial effluents- $a$ critical overview. 2012;1-34.

9. Ulutaş F, Alkaya E, Böğürcü M, et al. İzmir'de Eko-verimlilik Uygulamalarının Yaygınlaştırılması'na Yönelik Strateji Çalışması Raporu. İzmir Kalkınma Ajansı (İZKA), Türkiye Teknoloji Geliştirme Vakfı (TTGV), İzmir; 2012.

10. Global Ecolabelling Network. Introduction to Ecolabelling. 2004. p. $1-17$.

11. Sustainable Apparel Coalition.

12. UN Environment.

13. İnce ME. Konya Ticaret Odası Araştırma Raporları. Konya Ticaret Odas1. 2013.

14. Alkaya E, Böğürcü M, Dündar A, et al. Sanayide Eko-Verimlilik (Temiz Üretim) Kılavuzu: Yöntemler ve Uygulamalar. Desen Ofset, Ankara; 2011. p. 1-98.

15. Environmental Guidelines for Textiles Industry. p. 1-6.

16. United Nations Industrial Development Organization (UNIDO).

17. Fletcher K. Systems change for sustainability in textiles. Cambridge: Woodhead; 2009.

18. Kissa E. Fluorinated surfactants and repellents. New York: CRC Press; 2001. p. 640.

19. Shukla SR. Pollution abatement and waste minimization in textile dyeing. Environmental aspects text dyeing. 2007. p. 116-148.

20. Babu BR, Parande A, Raghu S, et al. Textile Technology An overview of wastes produced during Cotton Textile Processing and Effluent Treatment Methods. The Journal of Cotton Science. 2007;11:141-153.

21. Shaikh MA.Water conservation in textile industry. Pakistan Textile Journal. 2009;48-51. 
22. Glavič P, Lukman R. Review of sustainability terms and their definitions. Journal of Cleaner Production. 2007;15:1875-1885.

23. Katharine Earley. Industrial symbiosis: Collaborating to harness waste energy and materials for mutual benefit. 2015.

24. Gardner G, Assadourian E, Sarin R. The state of consumption today The World watch Institute. 2004.

25. Ströhle J, Benninger AG, Böttger D. Water and energy-saving solutions. Dyeing Printing \& Finishing, Textile World. 2008.

26. Gilding P. Sustainability-doing it. Allen \& Unwin, Australia; 2000.

27. Gardetti MA, Muthu SS. Handbook of Sustainable Luxury Textiles and Fashion. Singapore: Springer; 2015. p. 211.

28. Bright Hub. The Case of Nonionic Surfactants in Europe and America: To Ban or Not to Ban. 2010.

29. Fresner J. Cleaner production as a means for effective environmental management. Journal of Cleaner Production. 1998;6:171-179.

30. Allwood JM, De Rodriguez MC, Bocken NM. Well dressed? The present and future sustainability of clothing and textiles in the United Kingdom. Cambridge, UK; 2006.

31. Gupta KK. Polyvinyl alcohol size recovery and reuse via vacuum flash evaporation. PhD thesis, Georgia Institute of Technology. 2009.

32. Bayraktar T. Tekstil ve Konfeksiyon Sektöründe Ekoloji ve Ekolojik Etiketler. İstanbul Tekstil ve Konfeksiyon İhracatc1 Birlikleri, İstanbul. 2005 .

33. Turkey's Relations with the Organization for Economic Co-operation and Development (OECD).

34. Hoekstra AY, Chapagain AK, Aldaya MM, et al. The water footprint assessment manual: Setting the global standard. London: Eartscan; 2011. p. 228.

35. Wiedmann T, Minx J. A definition of 'carbon footprint'. Ecological economics research trends. 2008;1:1-11.

36. Darnerud PO, Eriksen GS, Johannesson T, et al. Polybrominated diphenyl ethers: occurrence, dietary exposure, and toxicology. Environ Health Perspect. 2001;109(1):49-68.

37. Greenhouse Gas Emissions. Understanding Global Warming Potentials

38. World Business Council for Sustainable Development

39. Jürgen Ströhle, Gerhard Schramek, Benninger AG. Textiles achieve ecological footprint: New opportunities for china. p. 1-7

40. Review of the Environmental Impact Assessment (EIA) Directive.

41. Clark G. Evolution of the global sustainable consumption and production policy and the United Nations Environment Programme's (UNEP) supporting activities. Journal of cleaner production. 2007;15:492-498.

42. Moore SB, Wentz M. Eco-labeling for textiles and apparel. Woodhead Publishing; 2009

43. Laxman MS. Pollution and its control in textile industry. Dyes and Chemicals. 2009.

44. Shenai VA. Non-ecofriendly textile chemicals and their probable substitutes-An overview. Indian J Fibre Text Res. 2001;26:50-54.

45. Khandare RV, Govindwar SP. Microbial Degradation Mechanism of Textile Dye and Its Metabolic Pathway for Environmental Safety. 2015. p. 399-439.

46. Textile links.
47. Jaganathan V, Cherurveettil P, Chellasamy A, et al. Environmental pollution risk analysis and management in textile industry: A preventive mechanism. European Scientific Journal. 2014;2:480-486.

48. Taşkın EG, Güney S. Tekstilde Environment-Textile Finishing Sector Project for the Creation of Sample Models for Cleaner Production-Technological Evaluation Report. Uludağ Exporters' Unions, Bursa Textile and Apparel, Technology, Incline Research, Consultancy and Energy Efficiency Services Limited Company, Bursa, Turkey; 2014.

49. Rott U, Minke R. Overview of wastewater treatment and recycling in the textile processing industry. Water Sci. Technology. 1999;40(1):137-144.

50. Chavan RB. Indian textile industry-environmental issues. Indian J Fibre \& Textile Research. 2001;26(1-2):11-21.

51. http://www.oecd.org/chemicalsafety/risk-assessment/

52. Jensen AA, Hoffman L, Birgitte TM, et al. Life cycle assessment (LCA): a guide to approaches, experiences and information sources. European Environment Agency, Environmental Issues Series. UK; 1997.

53. Sathaye J, Price L, de la Rue du Can S, Fridley D. Assessment of energy use and energy savings potential in selected industrial sectors in India. Bulletin on Energy Efficiency. 2005;6:25-28.

54. Tiwari M, Babel S. Air pollution in textile industry. Asian J Environmental Science. 2013;8(1):64-66.

55. Kumari P, Singh SSJ, Rose NM. Eco-Textiles: For Sustainable Development. International $J$ Scientific \& Engineering Research. 2013;4(4):1379-1390.

56. Stall-Meadows, Peek G. Recycled Household Textiles and Clothing. Oklahoma Cooperative Extension Fact Sheets. 2012.

57. The United Nations Environment Programme (UNEP). Cleaner production in the Asia Pacific Economic Cooperation Region. United Nations Publication, Thailand; 1994. p. 1-48.

58. Sharma S. Energy Management in Textile Industry. International $J$ Power System Operation \& Energy Management. 2012;2(1-2):45-49.

59. Kant R. Textile dyeing industry an environmental hazard. Natural Science. 2012;4(1):22-26.

60. Saxena S, Raja ASM, Arputharaj A. Challenges in Sustainable Wet Processing of Textiles. Textiles and Clothing Sustainability. 2017. p. 43-79.

61. Vietnam Cleaner Production Centre. Mini-guide to Cleaner Production VNCPC, Vietnam; 2000. p. 1-24.

62. Suzuki DT, Dressel H. Good news for a change: hope for a troubled planet. Stoddart Publishing. 2002. p. 288.

63. Güleryüz Ö. Textile Sector and Future in Turkey in Global Developments. MSc thesis, Isparta, Turkey; 2011.

64. Islam MM, Khan MMR. Environmental sustainability evaluation of apparel product: a case study on knitted T-shirt. J Textiles. 2014. p. 6

65. We make fashion sustainable. Newcell, Sweden

66. Colour index. Society of dyers and colourists.

67. Özbay A. Analysis of Cleaner Production Approach in Turkey and Institutional Restructuring for a Cleaner Production Center for SMEs. Expertise thesis, State Planning Organization, Ankara, Turkey; 2005.

68. Buck RC, Franklin J, Berger U, et al. Perfluoroalkyl and polyfluoroalkyl substances in the environment: terminology, classification, and origins. Integr Environ Assess Manag. 2001;7(4):513-541.

69. Visvanathan C, Kumar S, Han S. Cleaner production in textile sector: Asian scenario. Colombo, Sri Lanka; 2000. 
70. Budak Ç. Cleaner Production and Water Minimization Approaches in Industries Cleaner Production Practices in EU and Turkey: Textile Industry Example. Expertise thesis, Ministry of Environment and Urbanism, Ankara, Turkey; 2014.

71. Parvathi C, Maruthavanan T, Prakash C. Environmental impacts of textile industries. Indian Textile J. 2009.

72. Demirer GN. Basic Principles of Pollution Prevention Approaches, Environment and Engineer-TMMOB. 2003;25:13-20.

73. Frondel M, Horbach J, Rennings K. End-of-pipe or cleaner production? An empirical comparison of environmental innovation decisions across OECD countries. Centre for European Economic Research. 2004. p. 4-82.

74. World Commission on Environment and Development (WCED). Our common future. Oxford University Press, UK; 1987. p. 300.

75. Lombardi DR, Laybourn P. Redefining Industrial Symbiosis. J Industrial Ecology. 2012;16:28-37.

76. Brown BJ, Hanson ME, Liverman DM, et al. Global sustainability: toward definition. Environmental management. 1987;11(6):713-719.

77. Chen C, Lewis VD. The life of a piece of cloth: developing garments into a sustainable service system. International Journal of Environmental, Cultural, Economic and Social Sustainability. 2006;2(1):197-208.

78. Ulutas F, Alkaya E, Bogurcu M, et al. Clean (Sustainable) Production: Final Report on Determination of Framework Conditions and $\mathrm{R}$ \& D Need for Dissemination of Cleaner Production Applications in Turkey. International J Sustainable Development \& World Ecology. 2010;19(3):203-209.

79. Division textile. Kusters, India.

80. Cleaner production. Centric Austria, Austria.

81. Eser B, Çelik P, Çay A, et al. Sustainability and Recycling Possibilities in Textile and Apparel Sector. Textile \& Engineering. 2016;23.

82. Muthu SS, Li Y, Hu JY, et al. Carbon footprint reduction in the textile process chain: recycling of textile materials. Fibers Polym. 2012;13(8):1065-1070.

83. Zamani B. Towards Understanding Sustainable Textile Waste Management: Environmental impacts and social indicators. Thesis For The Degree Of Licentiate, Chalmers University of Technology, Sweden; 2014. p. $1-52$.
84. Environmental management system (EMS). US environmental protection agency.

85. Cooper P. Color in dyehouse effluent. Society of Dyers \& Colourists. 1995.

86. Elkington J. Cannibals with forks-The triple bottom line of 21 st century business. Capstone Publishing, UK; 1997. p. 424.

87. Eryuruk SH. Life cycle assessment method for environmental impact evaluation and certification systems for textiles and clothing. Elsevier. 2015.

88. Choudhury AKR. Environmental Impacts of the Textile Industry and Its Assessment through Life Cycle Assessment. Springer Science- Business Media, Singapore; 2014. p. 1-39.

89. Directive 2003/53/EC of The European Parliament and of The Council. European Union Official Journal. 2003.

90. Frankel C. In earth's company: business, environment, and the challenge of sustainability. New Society Publishers, Canada; 1998.

91. Dadi D, Stellmacher T, Senbeta F, et al. Environmental and health impacts of effluents from textile industries in Ethiopia: the case of Gelan and Dukem, Oromia Regional State. Environ Monit Assess. 2017;189(1):11.

92. The Life Cycle Inventory \& Life Cycle Assessment of Cotton Fiber \& Fabric Executive Summary. Cotton Incorporated. 2012

93. Nachhaltig wachsen. soexgroup.

94. https://www.patagonia.com/on/demandware.static/Sites-patagonia-us-Site/Library-SitesPatagoniaShared/en_US/PDF-US/common threads_whitepaper.pdf

95. Jeihanipour A, Karimi K, Niklasson C, et al. A novel process for ethanol or biogas production from cellulose in blended-fibers waste textiles. Waste Manag. 2010;30(12):2504-2509.

96. Caustic soda manufacturing plant. Indiamart.

97. Naveed S, Bhatti I, Ali K. Membrane technology and its suitability for treatment of textile waste water in Pakistan. $J$ Research (Science). 2006;17(3):155-164.

98. Tüfekci N, Sivri N, Toroz İ. Pollutants of textile industry wastewater and assessment of its discharge limits by water quality standards. Turkish J Fisheries \& Aquatic Sciences. 2007. 